\title{
The Impossible Schools: Rural Classrooms in the Paintings of Italian Artists During the Second Half of the Nineteenth Century
}

\section{Introduction}

This chapter examines the ways in which rural schools in Central and Southern Italy were represented in the works of local painters in the second half of the nineteenth century. ${ }^{1}$ The paintings stand out for their portrayal of classrooms as sparsely furnished, antiquated, poorly lit, and not particularly clean, alongside small groups of students taught by elderly schoolmasters ${ }^{2}$ still using the outmoded, individual method of instruction even after the introduction of the normal method.

Eight of the twenty-two rural school paintings analyzed portray unhealthy, rundown environments with dismal lighting, and a dearth of educational material. Indeed, none of the settings depicted were designed to be used as classrooms but were ordinary rooms in private homes or parish presbyteries. The paintings of Giuseppe Costantini (1844-1894), in particular, ${ }^{3}$ depict a shortage of chairs and benches, such

\footnotetext{
1 This paper drew on a sample of around 40 paintings and preparatory sketches by Achille Martelli, Ferdinando Cicconi, Michele Lenzi, Giuseppe Costantini, Francesco Bergamini, Vincenzo Loria, Augusto Daini, Gioacchino Toma, Demetrio Cosola, Giacomo Mantegazza and Alessandro Battaglia, three engravings and lithographs of some of these paintings and two original engravings by Antonio Piccinni. Twenty-eight of these visual sources (twenty-two depicting country schools in Southern Italy and six representing town schools in the North of the country) were selected for in-depth analysis and are listed in full at the end of the paper.

2 Of the twenty-two depicting Southern rural schools, those featuring lay and religious teachers invariably elderly male - numbered nineteen and nine, respectively: meanwhile, sixteen paintings included religious - themed wall shrines and frescos (especially those by Francesco Bergamini).

3 Giuseppe Costantini (1844-1894) was born in Nola (Naples). He completed his artistic studies at Naples' Istituto d'Arte and Accademia di Belle Arti [Academy of Fine Arts], where he was a pupil of Giuseppe Mancinelli (1813-1875). He subsequently perfected his artistic technique at the atelier of the painter Vincenzo Petroccelli (1823-1896). Returning to Nola, he was the head of the School of
}

Note: While this chapter was jointly conceived by the two authors, the writing of the manuscript was divided between them as follows: Juri Meda drafted Sections 1 and 3 and Simonetta Polenghi drafted Section 2. We wish to thank Veronica Borgiani, whose research for her undergraduate thesis "The Representation of Schools in Italian Painting in the Late Nineteenth Century: The Cases of Giuseppe Costantini and Francesco Bergamini," submitted in partial fulfilment of the requirements for the Degree in Cultural Heritage Management from the University of Macerata in the 2015-2016 academic year (thesis supervisor: Juri Meda), provided valuable reference material for this study. 
that many of the pupils had to remain standing while waiting for the teacher to invite them to the blackboard. In contrast, Francesco Bergamini's ${ }^{4}$ works almost invariably depict pupils seated on stools with handwoven straw seats or on benches (some of which were church pews), and using trestle tables that they could barely reach for writing desks. ${ }^{5}$ Seven of Costantini's paintings include a few rudimentary school desks occupied by male students alone, while female students continue to sit on benches

Applied Artistic Design until 1893, which was subsidized by the local town council and worker's society. He specialized in "genre painting", which offered realistic and highly detailed representations of rustic everyday scenes (following in the tradition of the Flemish school), usually set in poorly furnished and badly lit interiors. He mainly lived and worked in Naples and the Campania region. The artistic value of his work is borne out by the fact that his paintings are constantly bought and sold by leading Italian and international auction houses, for prices ranging between $€$ 5,000 and $€ 30,000$ (see Giuseppe Luigi Marini, ed., Il valore dei dipinti italiani dell'Ottocento e del primo Novecento: analisi critica, storica ed economica (Turin: Allemandi \& Co., 2009), 224-227). See: Ministero della Istruzione Pubblica - Direzione generale per le antichità e le belle arti, Notizie intorno alle scuole d'arte e di disegno italiane (Rome: Tipografia Cecchini, 1898), 245-246; Mariantonietta Picone Petrusa, "Costantini Giuseppe,” in Dizionario biografico degli Italiani, vol. 30 (Rome: Istituto dell'Enciclopedia Italiana, 1984); Mariantonietta Picone Petrusa, "Costantini Giuseppe,” in La pittura napoletana dell'Ottocento, ed. Franco Carmelo Greco, Mariantonietta Picone Petrusa and Isabella Valente (Naples: Tullio Pironti editore, 1993), 112; Leonardo Avella, Giuseppe Costantini da Nola, artista pittore (Naples, Rome: Libreria Editrice Redenzione, 1980).

4 Francesco Bergamini was born in Assisi (Perugia) in 1850. He received his artistic training in Assisi at the atelier of the painter Alessandro Venanzi (1838-1916), whom he assisted with the decoration of the Cathedral of Saint Rufinus in Assisi in 1883. He later moved to Rome, where he is believed to have met the Neapolitan painter Michele Cammarano (1835-1920) who, like Giuseppe Costantini, had studied at the Naples Academy of Fine Arts under Giuseppe Mancinelli. Bergamini also began to produce mainly "genre painting," for which there was a thriving market at the time, choosing rustic interiors and everyday scenes as his preferred subjects. He worked mainly in Rome and the Lazio region. While the precise date of his death has yet to be firmly established, he was still active in 1905. Bergamini has generally been overlooked by Italian art historians due, among other reasons, to a lack of access to his works, most of which are not held in Italian museums but rather in private collections around the world. The artistic value of his work is borne out by the fact that his paintings are constantly bought and sold by leading Italian and international auction houses, for prices that range between $€ 5,000$ and $€ 25,000$ (Giuseppe Luigi Marini, ed., Il valore dei dipinti italiani dell'Ottocento e del primo Novecento: analisi critica, storica ed economica.70-71). See: Antonio Cristofani, Delle storie di Assisi (Assisi: Tipografia Metastasio, 1902), 446; Ezio Genovesi and Emilio Lunghi, eds., Arte ad Assisi: 1882-1942. Catalogo della mostra (Bastia Umbra: Grafiche Diemme, 1993), 148-149; Ezio Genovesi, "Francesco Bergamini pittore," Subasio: trimestrale di informazioni culturali VI, no. 4 (1998): 22-23; Paola Mercurelli Salari, I disegni di Francesco Bergamini per la perduta decorazione ottocentesca della cattedrale di San Rufino ad Assisi (Assisi: Circolo del Subasio, 2005).

5 With regard to contemporary standards for school furnishings, useful insight was provided by Domenico Santucci in 1843, who remarked that: "The school tables should be one meter wide and arranged to face the schoolmaster's table. Schoolmasters are forbidden to use wide tables at which it is possible to seat two facing rows of pupils, given that this would hinder supervision" (Domenico Santucci, Guida dei precettori d'ambo i sessi e padri di famiglia per le scuole elementari comunali e private (Naples: Tipografia Agrelli, 1843), 114). 
(some paintings showed mixed classes, which was unusual in the period.) At a purely visual level, this reveals the deep-set gender inequalities in the post-Unification period, whereby male students were allowed to use desks because they needed to be literate in order to be allowed to vote (a privilege from which women were excluded), while female students were only expected to learn how to read.

The twenty-two paintings in our sample feature only seven blackboards, one abacus, and five wall maps or educational posters between them, showing that very few schools were equipped with the furnishings and teaching aids prescribed in Royal Decree No. 4336 of 15 September $1860 .^{6}$

Another key feature of these works is their representation of students as unruly, always ready to make fun of the teacher, pull cruel pranks, make disrespectful and mocking faces and gestures, steal food from behind his back, and move the hands of the clock forward so that lessons would finish sooner. ${ }^{7}$ These insolent rascals were severely reprimanded and regularly disciplined by their teachers, including use of so-called "shaming punishments" such as the dunce's cap ${ }^{8}$ and bit, ${ }^{9}$ which modern educational science strongly condemned and were prohibited under contemporary school legislation. ${ }^{10}$

The dreadful material state of schools in Southern Italy in the immediate aftermath of Unification, especially in rural or mountainous areas, are well-known. The paintings studied below essentially provide us with the opportunity to see the material conditions, reconstructed by historians using more traditional sources, with our own eyes. However, they also offer novel insights into other, less overt, dynamics. ${ }^{11}$

\footnotetext{
6 The basic classroom equipment described in Article 140 of the decree comprised: "School desks with seats in sufficient number for all pupils," a teacher's desk, a storage cupboard with a lock, a stove, "an inkwell for the teacher and fitted inkwells for the pupils," "a picture representing the basic units and measurements of the decimal metric system," a crucifix, and a portrait of the King. 7 Eighteen of the twenty-two paintings depicting southern Italian country schools represented episodes of unruliness - or, worse still, acts of mockery towards the teacher - by individual pupils or entire classes (an especially frequent theme in the works of Francesco Bergamini).

8 On this particular punishment, see: Juri Meda and Marta Brunelli, "The Dumb Child: Contribution to the Study of the Iconogenesis of the Dunce Cap," History of Education \& Children's Literature 13, no. 1 (2018): 41-70.

9 This "barbarically ingenious instrument" (as per Baldo Peroni's review of the below cited volume in Rivista Pedagogica, 2, no. 10 (1909): 1012) was described as "a wooden stick tied at both ends and placed in the mouths of chatterboxes in the manner of a bit" (Emilia Formiggini Santamaria, L'istruzione popolare nello Stato Pontificio, 1824-1870 (Bologna: A.F. Formiggini Editore, 1909), 144); a bit is also represented in the painting La scuola del villaggio (1888) by the artist Giuseppe Costantini.

10 The rod or cane [verga o ferula] used for corporal punishment is represented in eleven of the twenty-two paintings of rural schools in Southern Italy, generally being brandished as a warning by the schoolmaster; four of the twenty-two works (those of Giuseppe Costantini and Vincenzo Loria) depict actual punishments.

11 Since the early 2000s - starting with the seminal book Eyewitnessing: The Use of Images as Historical Evidence by Peter Burke (London: Reaktion Books, 2001) - international historiographical debate has seen an increasing number of scholars take interest in the heuristic potential of visual sources within the history of education: Ian Grosvenor, “On Visualizing Past Classrooms," in Silences and Images: The Social
} 
The gloomy picture of these schools shown by the artists deserves further analysis: more specifically, we need to ask what public image of education for the lower classes the artists wished to convey and to what ends? If mass education represented the preeminent tool to shape citizens of the new nation and provided a solid collective identity, what would be the point in discrediting it so ruthlessly by emphasizing its initial failures? This dilemma can only be resolved by going beyond formal analysis of these works to develop additional/alternative interpretive categories.

In recent years, historians of education have identified a need to broaden the heuristic scope of the discipline, no longer confining it to the study of schools as institutions and the places where educational practice and experimentation are implemented. Instead, we should examine the different ways in which schools have been symbolically represented over time, and how social perceptions of schooling and the teaching profession have evolved, as indicators reflecting the complex cultural dimension of this intricate historical phenomenon. For example, in a celebrated article from 2000, Portuguese historian António Nóvoa invited fellow scholars to not only analyze schooling of the past "from inside" (i.e., schools as they really were, or at least, as they represented themselves), but also "from the outside" (i.e., as they were perceived in the wider community), with a view to building up a broader perspective on schooling as a historical phenomenon. ${ }^{12}$ Within such a conceptual framework, the school is no longer seen solely as a historical object, but also

History of the Classroom, ed. Ian Grosvenor, Martin Lawn, and Kate Rousmaniere (New York: Peter Lang, 1999), 83-104; Kate Rousmaniere, "Questioning the Visual in the History of Education," History of Education 30, no. 2 (2001): 109-111; Eulàlia Collelldemont, "La memoria visual de la escuela," Educatio Siglo XXI 38, no. 2 (2010), 133-156; see also the special issues: Marc Depaepe and Bregt Henkens, eds., "The Challenge of the Visual in the History of Education," Paedagogica Historica 36, no. 1 (2000); Karin Priem, Inés Dussel, and Marc Depaepe, eds., "Images and Films as Objects to Think With: A Reappraisal of Visual Studies in Histories of Education," Paedagogica Historica 53, no. 6 (2017). More narrowly, on the use of engravings and paintings as sources for the history of education, see: Jeremy Charles Howard, "Classroom Genres: Aspects, Values and Interpretations of Painted School Interior Scenes," in The Black Box of Schooling: A Cultural History of the Classroom, ed. Sjaak Braster, Ian Grosvenor, and María del Mar del Pozo Andrés (Brussels: Peter Lang, 2011), 59-77, 292-293, 313-317; Juan Antonio Gómez Naranjo, "La escuela del Siglo XVII, según la pintura de Jan Steen,” Anales de historia del arte 21, no. extra 1 (2011): 241-247; Jeroen J.H. Dekker, "Images as Representations: Visual Sources on Education and Childhood in the Past,” Paedagogica Historica 51, no. 6 (2015): 702-715; María del Mar del Pozo Andrés and Sjaak Braster, "Exploring New Ways of Studying School Memories: The Engraving as a Blind Spot of the History of Education," in School Memories. New Trends in the History of Education, ed. Cristina Yanes-Cabrera, Juri Meda, and Antonio Viñao (Cham: Springer, 2017), 11-27; Jeroen J.H. Dekker, "The Restrained Child: Imaging the Regulation of Children's Behaviour and Emotions in Early Modern Europe, The Dutch Golden Age," History of Education \& Children's Literature 13, no. 1 (2018): 17-39; Jeremy Charles Howard, "Le traitement artistique de la culture matérielle à l'école," in Éducation et culture matérielle en France et en Europe du XVIe siècle à nos jours, ed. Marguerite Figeac-Monthus (Paris: Honoré Champion, 2018), 219-246. The heuristic underpinnings of this paper are contained in the studies above.

12 This need has also recently been emphasized in: Juri Meda and Antonio Viñao, "School Memory: Historiographic Balance and Heuristic Perspectives,” in School Memories, 5. 
as a category in the social imaginary, whose visual representations might not necessarily correspond to what schools were really like in a given period, but rather reflect how they were perceived by a given social group or by society as a whole. ${ }^{13}$

\section{The Individual Method of Instruction, Insubordination, and Corporal Punishment: The Scourges of Southern Italian Schools}

The crucial starting point for analyzing this set of paintings is the state of public education in Italy in the years immediately following Unification. ${ }^{14}$ The general report on the status of the public school system presented to the Minister by the Advisory Board for Public Education in 1865 already outlined a complex situation. On scrutinizing the responses of the Schools Inspectorate for the province of Naples to the questions asked by the Board, we learn, for example, that in relation to the teaching methods used by schoolmasters, "the simultaneous method is used in most schools, but in many the individual method is used too, given the teachers' lack of familiarity with better methods," 15 while, with regard to pupil behavior in the classroom, it was observed that they were "beginning to become inured to discipline, in those places where schoolmasters had succeeded in introducing it." 16 For that matter, maintaining discipline in the classroom was a problem all over the country, as was clearly reflected in the data collected by the provincial school inspectorates on the punishments typically used by teachers. While, on the whole, the inspectors reported that corporal punishment had been successfully abolished, and the new regulations issued on 15 September 1860 on disciplinary measures in schools were being implemented, ${ }^{17}$ nevertheless in 1863 the Arezzo inspectorate found

\footnotetext{
13 See António Nóvoa, "Ways of Saying, Ways of Seeing: Public Images of Teachers (Nineteenth Twentieth Century)," Paedagogica Historica 36, no. 1 (2000): 20-52.

14 The selected works all date roughly to the period between 1869 and 1895. On schools, schoolmasters, and teaching methods in southern Italy prior to Unification, see: Maurizio Lupo, Tra le provvide cure di Sua Maestà: Stato e scuola nel Mezzogiorno tra Settecento e Ottocento (Bologna: Il Mulino, 2005); Salvatore Agresta and Caterina Sindoni, Scuole, maestri e metodi nella Sicilia borbonica (1817-1860) (Lecce, Rovato: Pensa Multimedia, 2012), 4 vol.; Salvatore Agresta and Caterina Sindoni, Scuole, maestri e maestre nelle Calabrie borboniche (1817-1860) (Lecce, Rovato: Pensa Multimedia, 2106).

15 Sulle condizioni della pubblica istruzione nel Regno d'Italia: relazione generale (Milan: Stamperia Reale, 1865), 455.

16 Sulle condizioni della pubblica istruzione nel Regno d'Italia: relazione generale (Milan: Stamperia Reale, 1865), 429.

17 Article 98 of the new set of regulations was clear on this topic: "It is forbidden to use offensive language, blows, marks of shame, and corporal punishment, such as forcing [pupils] to go down on their knees, spread out their arms, etc., or to assign tasks as a punishment, with the exception of repeating work that has been badly done."
} 
that schools "had still not dropped the abominable custom of beating pupils." "Its Naples counterpart laconically admitted that "unfortunately corporal punishment is still in use in many schools in this province". ${ }^{19}$ The state of public education in the province of Naples was to remain problematic for the entire next decade, as recorded by the Commissions of Inquiry into elementary school education, appointed in 1868 by Minister Emilio Broglio and in 1869 by Minister Cesare Correnti. The commission worked on proposals for increasing the number of municipal elementary schools, especially in the south, and reducing the high rate of early school leaving.

The artists Achille Martelli, ${ }^{20}$ Ferdinando Cicconi, ${ }^{21}$ Giuseppe Costantini, Francesco Bergamini, Vincenzo Loria, ${ }^{22}$ Augusto Daini, ${ }^{23}$ and Gioacchino Toma ${ }^{24}$ all

18 Sulle condizione della pubblica istruzione nel Regno d'Italia, 432.

19 Sulle condizione della pubblica istruzione nel Regno d'Italia, 433.

20 Achille Martelli was born in Catanzaro on January 16, 1829. He trained as an artist at the Naples Academy of Fine Arts, where - like Costantini - he was a student of Giuseppe Mancinelli. He specialized in painting interiors, depicting domestic scenes in a realistic style and identifying most closely with the artistic current then seeking to narrate everyday life. He died in Avellino on December 12, 1903. See Isabella Valente, "Centro e periferia: itinerari italiani di alcuni artisti calabresi tra Ottocento e Novecento," in L'animo e lo sguardo: pittori calabresi dell'Ottocento di Scuola napoletana. Catalogo della mostra, ed. Tonino Sicoli and Isabella Valente (Cosenza: Progetto 2000, 1997), 17-34; Giorgio Leone, "La Calabria tra Napoli e il resto d'Italia. La "pittura di interno" come un episodio pittorico della cultura artistica del Mezzogiorno nella seconda metà dell'Ottocento," in Poesia d'interni angoli di vita nell'arte dell'800 italiano, ed. Antonio D’Amico (Milan: Edizioni Bocca, 2010), 17-22.

21 Ferdinando Cicconi was born in Colli del Tronto (Ascoli Piceno) in 1831. He initially studied under Ignazio Cantalamessa in Ascoli Piceno; he later moved to Rome, where he encountered great artists such as Tommaso Minardi and Francesco Podesti at the Accademia Nazionale San Luca. On returning to his home region of the Marches, he became a drawing teacher at Ancona Technical School. Cicconi specialized in historical compositions featuring great epic figures of the past, for example devoting an entire cycle of works to Christopher Columbus. He was also fond of patriotic themes. He mainly lived and worked in the Marches. He died in 1886. See Ernesto Ovidi, Tommaso Minardi e la sua scuola (Rome: Tipografia Pietro Rebecca, 1902); Luca Luna, Ferdinando Cicconi (Ascoli Piceno: D’Auria Editrice, 1996).

22 Vincenzo Loria (1849-1939) was born in Salerno. He initially took up painting under the guidance of the French master, Leon Richter, and later enrolled at the Naples Academy of Fine Arts, where he became a student of Domenico Morelli (1823-1901). He mainly produced oil and watercolor paintings, of which the most popular were his Neapolitan landscapes and views of Pompei. He died in La Spezia on October 31, 1939. Loria worked particularly hard to supply the foreign market; indeed, most of his paintings were purchased by English customers. See Giuseppe Luigi Marini, ed., Il valore dei dipinti italiani dell'Ottocento e del primo Novecento: analisi critica, storica ed economica (Turin: Allemandi \& Co., 2007), 522.

23 Augusto Daini (1860-1920) studied at the Rome Academy of Fine Arts. On completion of his training, by which time he was an accomplished watercolor artist, he worked for many years as a salaried employee of the painter Pietro Barucci, specializing in realistically depicted rural areas, especially the Roman countryside. He died in Rome in 1920. See Renato Mammucari, Acquerellisti romani: suggestioni neoclassiche, esotismo orientale, decadentismo bizantino, realismo borghese (Città di Castello: Edimond, 2001), 163.

24 Gioacchino Toma (1836-1891) was born in Galatina (Lecce). From there, he moved to Naples where he attended the Academy of Fine Arts, eventually joining the teaching staff in 1878. He died 
lived and worked in Lazio and Campania in the second half of the nineteenth century. Their paintings confirm the continued use of the individual method in many rural schools in the regions, as well as schoolmasters' difficulties to keep order in the classrooms and the consequent use of corporal punishment.

In the wake of national unification, educational scientists universally viewed the normal method as the best approach. Nevertheless, many teachers, and particularly older ones, had not yet adopted it, continuing to rely on either the more traditional methods of individual or mutual instruction. ${ }^{25}$ The normal method allowed teachers to teach a large number of pupils at the same time. All students would be seated and listen to the lesson given by the teacher before quietly completing the learning tasks assigned to them.

The multiple advantages associated with adopting the normal method were presented by the head of the "Santucci" School in Capodimonte in Naples, Domenico Santucci, in his guideline document for elementary teachers of both sexes and fathers of school-going children, "Guida dei precettori d'ambo i sessi e padri di famiglia per le scuole elementari comunali e private" (1843). Santucci criticized the individual method of instruction, which continued to find favor with older teachers. Blinkered by their own long-entrenched prejudices, these schoolmasters boasted of their ability to "succeed in their lofty mission with their cane in their hand, with the belt or the whip." 26 Santucci observed that:

in Naples in January 1891. His paintings were on primarily historical themes, with a focus on representing feelings and psychological states. See Paolo Ricci, "Gioacchino Toma e la pittura meridionale dell'Ottocento," Società 11, no. 3 (1955), 458-79; Bruno Mantura and Nicola Spinosa, eds., Gioacchino Toma: 1836-1891. Catalogo della mostra (Naples: Electa, 1995).

25 Numerous studies have described the rapid spread of the normal method throughout Italy. Notably, Simonetta Polenghi has provided a detailed account of how the rise of the normal methodwas facilitated by its early introduction in Lombard schools under the Austrian Empire and specifically during the ten-year reign of Joseph II; its subsequent extension to the schools of the Napoleonic Kingdom of Italy; and finally its prescription by law in the schools of the Kingdom of Lombardy-Venetia, where it initially became a model for the school systems of the other pre Unification states and, afterward, for the Italian school system. On this topic, see Maria Cristina Morandini, Scuola e nazione: maestri e istruzione popolare nella costruzione dello Stato unitario (1848-1861) (Milan: Vita e Pensiero, 2003); Giorgio Chiosso, Alfabeti d'Italia: la lotta contro l'ignoranza nell'Italia unita (Turin: Società Editrice Internazionale, 2011); Simonetta Polenghi, "La pedagogia di Felbiger e il metodo normale," Annali di Storia dell'Educazione e delle Istituzioni Scolastiche 8, (2001), 245-268; Simonetta Polenghi, "Elementary School Teachers in Milan During the Restoration (1814-59): Innovations and Improvements in Teacher Training,"History of Education \& Children's Literature 8, no. 1 (2013), 147-166.

26 Santucci, Guida dei precettori d'ambo i sessi e padri di famiglia per le scuole elementari comunali e private, 54. 
All the pupils in the school, with this [normal] method, are divided into classes according to their level of instruction, they read, write, do sums and repeat their lessons all together [. . .] The time spent in the classroom serves to enable the pupils' progress, and they work hard to emulate, a key motivating factor for the human soul. A school that is organized on the basis of this method can ensure that all its classes are working at the same time in an orderly and disciplined manner. [. . .] The individual method, in truth, provokes boredom, disgust, and the loss of a great deal of time, from both the students and the teachers' point of view. It deserves to be evicted from the sanctuary of public and private education, if the bias towards pedantry does not sustain it further. The normal method, with differs from the aforementioned method, is the only one that has received a joyful welcome in urban schools, advanced schools, and classical studies schools alike. In the classes where this method is applied, one teacher instructs all the pupils for the entire duration of the lesson; the students compare notes, thus further benefiting from mutual exchange, in contrast with classes where the individual method is deployed, in which the pupils are often left without the attention of the teacher, and lack discipline and order. ${ }^{27}$

It is striking that, in the account offered by Santucci, the decisive reason for adopting one method over the other was essentially disciplinary rather than pedagogical in nature. The leading advantage of the normal method was its contribution to the maintenance of discipline in the classroom - a widespread issue at the time - and a key prerequisite for orderly lessons and systematic enculturation. The individual method bored students as it was too slow, leading them to become impatient, disobedient, and disrespectful; in turn, it induced teachers to mete out punishment, including corporal punishment. Meanwhile, the normal method fostered order and discipline, as were divided into classes based on their current academic level and kept constantly occupied for the entire duration of the lesson. In short, the normal method was seen as a system that contributed to maintaining class discipline, significantly reducing the need for disciplinary action by the teacher; in contrast, a key feature of the individual method was teacher intervention with frequent recourse to tools of correction to restore order in the classroom. ${ }^{28}$

27 Santucci, Guida dei precettori d'ambo i sessi e padri di famiglia per le scuole elementari comunali e private, $55-57$.

28 However, this reading is incomplete. What may seem to be a method based on a significant decrease in the need for disciplinary action in learning environments was actually based on a newer, and more subtle form of discipline via the internalization of ethical norms (James Van Horn Melton, Absolutism and the Eighteenth-Century Origins of Compulsory Schooling in Prussia and Austria (Cambridge: Cambridge University Press, 1988). The disciplining of pupils' bodies by placing them in a rigid, panoptic device (the classroom), and the transmission of the "hidden curriculum" that has been discussed by numerous scholars. In this new context, therefore, power was no longer expressed through the exercise of physical violence, but rather through the distribution of bodies in a space with certain characteristics based on particular criteria for hierarchical organization. On these aspects more generally, see Thomas Marcus, "Early Nineteenth Century School Space and Ideology,” Paedagogica Historica 32, no. 1 (1996): 9-50; Inés Dussel and Marcelo Caruso, La invención del aula. Una genealogía de las formas de enseñar (Buenos Aires: Santillana, 1999); Marc Depaepe et al., Order in Progress: Everyday Educational Practice in Primary Schools (Belgium, 1880-1970) 
In the years following Unification, the problems raised by Santucci continued to plague many Southern Italian schools where, as depicted in our visual sources, the individual method continued to be widely used, especially in country schools. Umberto Zanotti White was still observing, in a report dated 1925, the outcomes of an inquiry into Calabrian schools commissioned by the Associazione Nazionale per gli Interessi del Mezzogiorno d'Italia [National Association for the Interests of Southern Italy]:

When it is sunny, the children are in the fields at the service of their parents or landlord. This explains the marked inequalities among children enrolled at, attending, or completing school. Families cannot accept the hours of compulsory schooling required of their children. They prefer individual teaching because it facilitates their need for access to their children, whom they can then send into the fields with their flocks or groups of olive pickers. ${ }^{29}$

Indeed, in the most culturally backward areas of Southern Italy, the individual method survived for an even longer stretch of time.

\section{The Representation of Country Schools in the Work of Southern Italian Painters}

The paintings of Achille Martelli, Ferdinando Cicconi. Giuseppe Costantini, Francesco Bergamini, Vincenzo Loria, Augusto Daini, and Gioacchino Toma thus represented southern elementary schools in all their harsh reality. Most of the artists specialized in "genre painting", which focused on rustic interiors and scenes from everyday life, representing them as realistically as possible and with an eye for detail. The generally small size of these paintings made them particularly suited for display in the houses of middle-class buyers, who were interested in decorating their homes, and not interested in the portraits or celebratory "historical paintings" that held greater appeal for the upper classes. This newly emergent social class, now in the running to lead the newly unified state, provided a boost to the art market, inducing painters and engravers - who could no longer count on the patronage of aristocrats as in the past - to quickly adapt to the taste of their audiences by depicting popular subjects and displaying their works in exhibitions and galleries.

(Louvain: Leuven University Press, 2000); Catherine Burke, "Containing the School Child: Architectures and Pedagogies," Paedagogica Historica 41, 4-5 (2005): 489-490; Jon Prosser, "Visual Methods and the Visual Culture of Schools," Visual Studies 12, no. 1 (2007), 13-30; Marcelo Caruso, ed., Classroom Struggle: Organizing Elementary School Teaching in the Nineteenth Century (Frankfurt am Main: Peter Lang, 2015).

29 Umberto Zanotti Bianco, Il martirio della scuola in Calabria (Florence: Vallecchi, 1925). 
While their works cannot, for these reasons, be construed as deliberate exercises in social commentary, it will be nonetheless be valuable to explore what image of public schooling these artists meant to convey for the humbler classes, and what feelings they wished to arouse in their audiences, apart from an initial, instinctive appreciation of amusing, everyday scenes. The liveliness of these scenarios - whose leading motifs are practical jokes, upheaval, punishment, and contrition ${ }^{30}$ (Figs. 10.1-10.2) - was a key selling point in the eyes of middle-class customers, who were not, as a rule, deeply interested in public critiques underlining the substandard life conditions of the less-welloff. Nevertheless, it would appear that the artists set out to express something more than a mere desire to cater for popular taste.

For example, in his Nella scuola del villaggio or O tempora! o mores! (1869), the Calabrian painter Achille Martelli depicted a village school based in a parish priest's house, where unsupervised pupils are caught by their teacher playing with the clergyman's Missal and religious vestments. Only two of the students appear to be aware of the teacher's presence, who stands in the doorway with a severe expression on his face. The first student has cast his head down in fear, while the other appears to await his merited rebuke. There is a vein of irony in this painting, underscored by citing Cicero in the title, whereby the painter appears to emphasize the discrepancy between the children's innocent game of make-believe and the disproportionately severe inquisition that is likely in store for them.

Martelli's teacher parish priest is not the only one in our sample of paintings. Indeed, in the Southern Italian regions, parish schools run by the parish priest himself were still a widespread phenomenon. The priests were hostile to the notion of state

30 It is interesting to note that practical jokes are a recurrent motif in nineteenth-century "genre painting" in general, and appear not only in school-themed works but also in religious-themed scenes, which were also quite popular in the period. Indeed, numerous contemporary paintings show incorrigible young altar boys playing jokes on ancient parish priests and, when caught redhanded, being soundly punished for their pains. In relation to this theme, see the following paintings: Francesco Bergamini, Il sermone del chierichetto, oil on canvas, n.d., 45.1 x $67.9 \mathrm{~cm}$., private collection (this painting - authenticated by the artist himself - was sold for US\$10,625 under the title "The altar boys' sermon" (Lot 62) by Bonhams auction house in New York on April 25, 2012 at an auction entitled "European Paintings"); Francesco Bergamini, In sacrestia, oil on canvas, n.d., $67.5 \times 44.7 \mathrm{~cm}$., private collection (the painting - authenticated by the artist himself - was sold for $€ 3,125$ under the title "Dans la sacristie" (Lot 371) by Christie's of Paris on April 14, 2015, at an auction entitled "Le Goût Français: arts décoratifs du 18e siècle au 19e siècle"); Demetrio Cosola, Chierichetti sorpresi in flagrante, oil on canvas, n.d., 68 x $92.5 \mathrm{~cm}$., private collection (the painting authenticated by the artist himself - was sold for $€ 8,750$ under its original title (Lot 7) by the Dorotheum auction house in Vienna on April 8, 2014 at an auction entitled "Gemälde des 19. Jahrhunderts"). The names of the owners of these works are protected by the data protection act, as are those of the works sold at the other auctions cited later in this paper. 


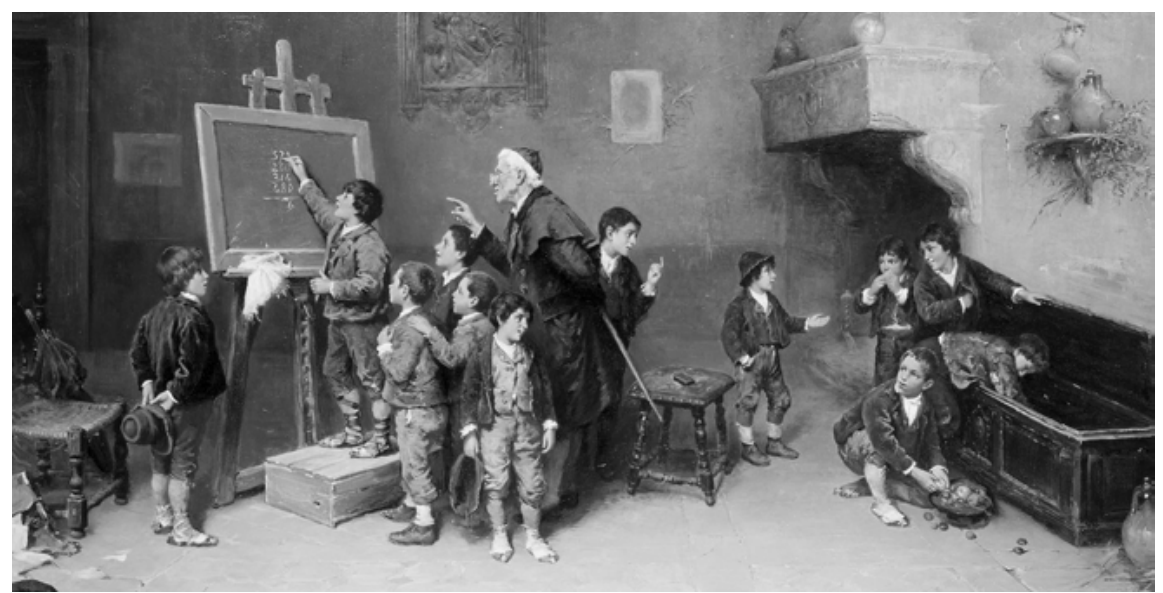

Fig. 10.1: Francesco Bergamini, Una lezione importante, oil on canvas, n.d., 50.5 x $81 \mathrm{~cm}$. [Private collection].

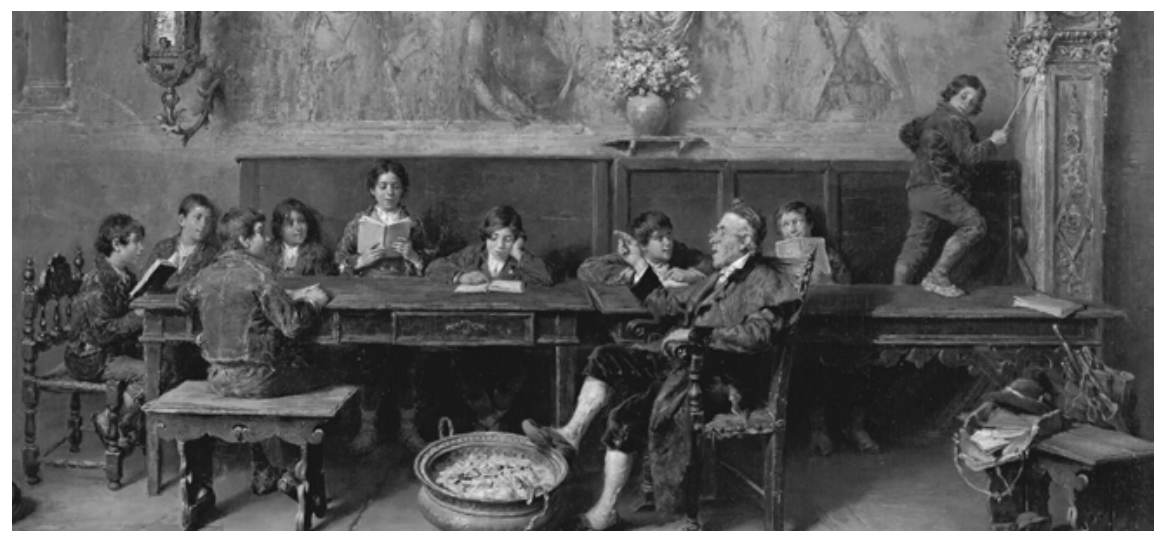

Fig. 10.2: Francesco Bergamini, L'alunno disubbidiente, oil on canvas, n.d., $55.3 \times 90 \mathrm{~cm}$. [Private collection].

education, which they saw as usurping their educational prerogatives. ${ }^{31}$ By associating members of the clergy with a reactionary and conservative approach to education, and sympathetically representing the children's innocent, though irreverent, playacting, a

31 Indeed, in the general report on the state of public education in Italy presented to the Minister in 1865 by the Advisory Board for public education, the provincial inspectorate of Naples went on record as stating that "the reactionaries see the [lay] teachers as excommunicated" (Sulle condizione della pubblica istruzione nel Regno d'Italia, p. 446). 
number of the artists in our sample made their profoundly anti-clerical leanings obvious.

Martelli's painting also reflects his disappointment as an artist who had participated in the Naples uprisings of 1848 and 1860 - along with Michele Lenzi ${ }^{32}$ and other fellow students at the city's Academy of Fine Arts. He had fought alongside Garibaldi's men against the Bourbon army - only to find almost ten years later that the ideals for which he had fought had not yet materialized. The liberal ruling class saw public education as both the key means of delivering the masses from the state of blind ignorance they had been kept in for centuries by clerical obscurantism, and the instrument par excellence by which to mold the new Italian people and develop a solid national culture.

A similar view of public education appears to have been shared by Giuseppe Costantini and Vincenzo Loria, ${ }^{33}$ whose works - which are less lively and ironic than Bergamini's - appear to express the pressing need for a network of elementary schools across the nation, with a view to completing the process of Italian unification and creating a true Italian people. Particularly representative works of this need include the renowned and frequently reproduced La scuola del villaggio (1886) ${ }^{34}$ (Fig. 10.3) and La scuola del villaggio (1888) (Fig. 10.4). However, many similar works by Costantini that also depict scenes of everyday school life were auctioned off in the late 1970s and early 1980s, winding up in private foreign collections. ${ }^{35}$

32 Michele Lenzi (1834-1886) - who like Martelli and Costantini had undergone artistic training at the Naples Academy of Fine Arts under Giuseppe Mancinelli - received an award at the Esposizione italiana agraria, industriale e artistica [Italian Agricultural, Industrial and Artistic Exhibtion] in Florence in 1861 for his painting Una scuola di bambine [A Girls' School], whose whereabouts is currently unknown (Esposizione Italiana Agraria, Industriale e Artistica tenuta in Firenze nel 1861: catalogo ufficiale (Florence: Tipografia Barbèra, 1862), 336).

33 Vincenzo Loria's Boys and teacher in a school interior which was sold by auction in 2009 is an exact copy of the main scene in La scuola del villaggio [The Village School] (1888) by Giuseppe Costantini.

34 A rotogravure color print $(23.7 \times 29.9 \mathrm{~cm}$.) of this painting was produced in 1886 by the Danesi printing company in Rome [Musée National de l'Éducation, Rouen (France); invent.: 1996.02280].

35 These were: Aula in campagna [Country Classroom], oil on canvas, n.d., 24.5 x $35.6 \mathrm{~cm}$., which sold for L.3,000,000 (Catalogo Bolaffi della pittura italiana dell'Ottocento, no. 8 (Turin: Bolaffi, 1979), 60); Aula in campagna [Country Classroom], oil on canvas, n.d., 23 x $34 \mathrm{~cm}$., which sold for L.6,800,000 (Catalogo Bolaffi della pittura italiana dell'Ottocento, n. X (Milan: Mondadori, 1981), 65); La scuola dei discoli [The School of Rascals], oil on canvas, n.d., $61 \times 37,5 \mathrm{~cm}$., sold for L.30,000,000 (Catalogo dell'arte italiana dell'Ottocento, n0. 13 (Milan: Mondadori,1984), 227); Scuola di campagna [Country School], oil on canvas, n.d., 18 x 24 cm., sold for L.10,000,000 (Catalogo dell'arte italiana dell'Ottocento, no. 14 (Milan: Mondadori, 1984), 201); Scherzi in classe [Classroom Pranks], oil on canvas, n.d., 35 x $25 \mathrm{~cm}$., was put up for auction by Finarte auction house in Rome on October 25-26, 1983 and sold for L.18,000,000 (Catalogo dell'arte italiana dell'Ottocento, no. 13 (Milan: Mondadori, 1984), 227); La lezione di matematica [The Maths Lesson], oil on canvas, n.d., 25 x 35 cm., was put up for auction by L'Antonina auction house in Rome on December 9, 1993 but did not sell (Giuseppe Luigi Marini, ed., Il valore dei dipinti italiani dell'Ottocento e del primo 


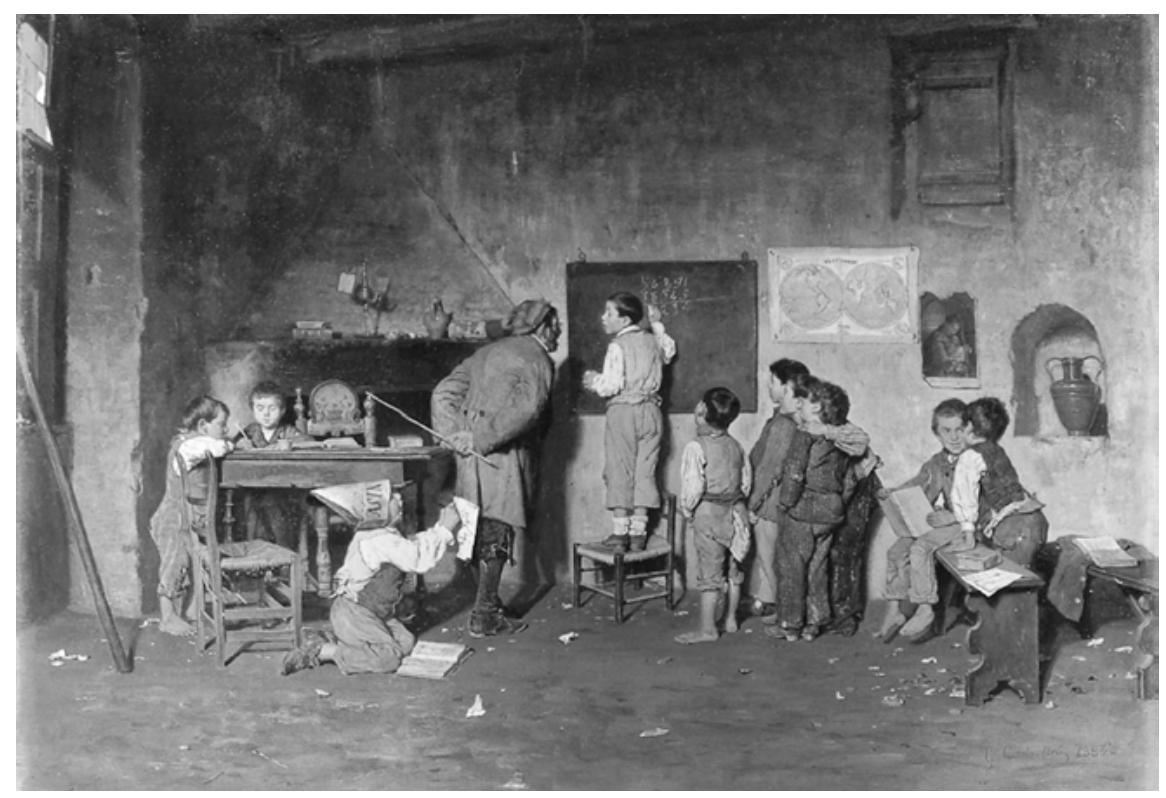

Fig. 10.3: Giuseppe Costantini, La scuola del villaggio, oil on canvas, 1886 [Galleria Nazionale d'Arte Moderna, Rome - Italy].

Ferdinando Cicconi was another artist with a patriotic agenda. He painted a number of works celebrating Risorgimento battles, and, unlike the other artists we have analyzed thus far, set his school themed paintings in schools in the preUnification states, with a view to contrasting their outdated educational methods with the more modern approaches adopted in the schools of the newly united nation. For example, in his painting La Scuola dei vecchi tempi [The School of Bygone Times] (n.d.), - as described in an article by Raffaele Mariani - Cicconi depicted certain punishments that were no longer allowed under the Decree of September 15, 1860, including "a donkey mask, that, in the manner of a helmet, would be slipped over the guilty pupil's head and down over his eyes, so that the ears, made of papiermâché, would be positioned at either side of the face", "the culprit being required to

\footnotetext{
Novecento: analisi critica, storica ed economica (Turin: Allemandi \& Co., 1995), 171). It should be noted that the two versions of the painting Aula di campagna are both preparatory studies for $L a$ scuola del villaggio of 1886, while the painting Scuola di campagna is a preparatory study for La scuola del villaggio of 1888. On December 14, 2019, the Galleria Sarno in Palermo auctioned a preparatory study for La scuola del villaggio (Lot 447), oil on canvas, n.d., 43.5 x $31.5 \mathrm{~cm}$. for €1,800; given that the measurements of the painting as reported in the auction catalogue (p. 95) do not coincide with those of the two versions of Aula di campagna, it appears that it may have been a third preparatory study for La scuola del villaggio of 1886.
} 


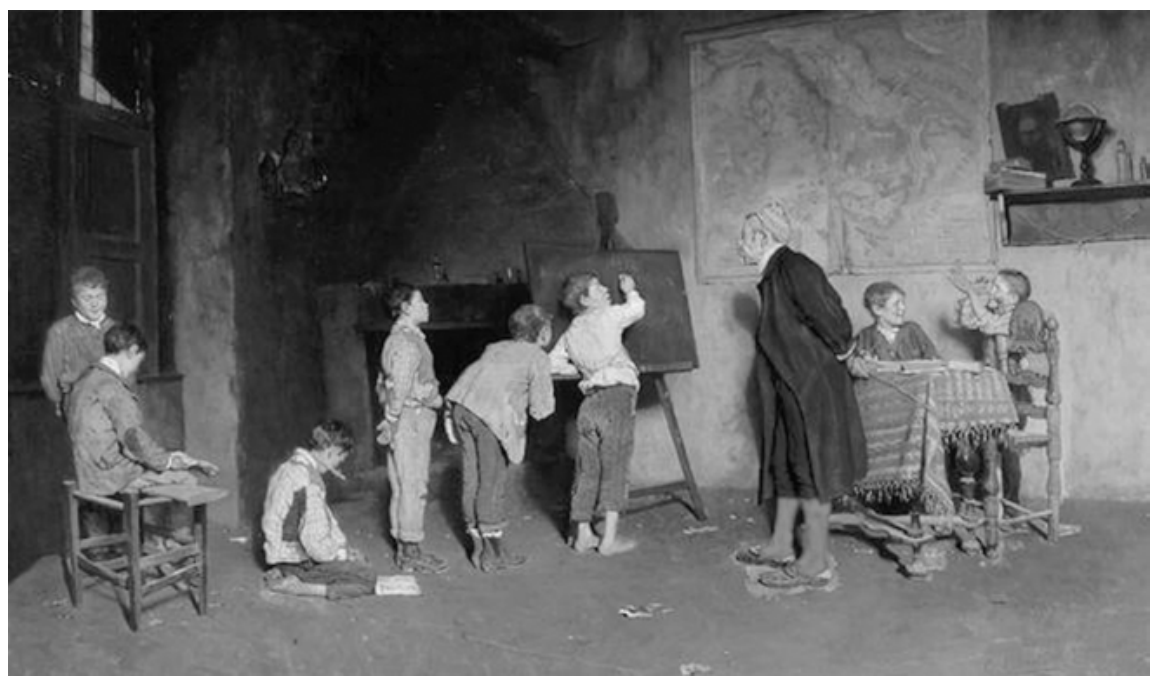

Fig. 10.4: Giuseppe Costantini, La scuola del villaggio, oil on canvas, 1888, $40.1 \times 63.7 \mathrm{~cm}$. [Calderdale Metropolitan Borough Council Museums and Arts, Halifax - United Kingdom].

stand at attention" 36 and the punishment of the horse, that "consisted in striking with a whip one who is lifted up on the back of another". ${ }^{37}$ Cicconi's ideological perspective on corporal punishments used in the schools of pre-Unification states recurred in his painting La scuola sotto i passati governi [School Under Past Governments], in which the walls of an almost empty classroom - themselves resembling "chewed bread" were adorned with a handwritten notice that proclaimed: "Che buon pro facesse il verbo / Imbeccato a suon di nerbo / Nelle scuole pubbliche” [What good is the word / Prompted by the sound of the whip / In public schools]. ${ }^{38}$

36 Raffaele Mariani, “Castighi scolastici di altri tempi,” I Diritti della Scuola 30, no. 13 (1929): 605. The author of the article from which we have drawn this description of the work presumably had the opportunity to view it at the Pinacoteca civica in Ascoli Piceno between 1896 and 1913, when as the records show - he was a school inspector in Ascoli Piceno and the painting was still on display at the local museum, before being withdrawn by the artist's heirs.

37 Giuseppe Rigutini, Vocabolario della lingua italiana (Florence: Barbèra, 1874), 233. The fact that this punishment was widely practiced is born out by the many references to it in folk culture, as in the expression "fare il latino a cavallo" [to do Latin on horseback], used to describe a person who is forced to do something (Vocabolario degli Accademici della Crusca, vol. 2 (Florence: Tipografia Galileiana, 1866), 709) or the Tuscan proverb "La prima si perdona, alla seconda si bastona e alla terza si dà il cavallo" [The first time you forgive, the second time you strike, and the third time you give the horse] (Giuseppe Giusti, Raccolta di proverbi toscani (Florence: Le Monnier, 1853), 86).

38 Pietro Ferrigni, Fra quadri e statue: strenna ricordo della II Esposizione nazionale di belle arti (Milan: Treves, 1873), 195. The verses cited are drawn from the opening of the composition Glimmobili e $i$ semoventi, in Versi editi ed inediti by Giuseppe Giusti, in which the Tuscan writer decried the excessive 
We may usefully conclude our analysis by comparing these representations of rural schools in Southern Italy with paintings of urban schools from the same period, such as L'onomastico della maestra (1879) by Gioacchino Toma, Il dettato (1891) and L'asilo (n.d.) by Demetrio Cosola, La lezione allo scolaro or Chi la fa l'aspetta (s.d.) by Giacomo Mantegazza $^{39}$ (Fig. 10.5), and In classe (1897) by Alessandro Battaglia. This group of paintings contrasts with earlier examples by depicting classrooms as pleasant, spotlessly clean, and well equipped with desks and teaching aids, such as geographical maps, wall charts, textbooks, and exercise books. In these classrooms, lessons went smoothly and without disruption, under the watchful gaze of the teacher. The only exception to this overall pattern is the painting La lezione allo scolaro o Chi la fa l'aspetta (s.d.) by Giacomo Mantegazza (Fig. 10.5), which represents a schoolmaster on the point of punishing a pupil who has injured a classmate in the head; the teacher is holding the boy firmly by the ears and getting ready to administer the punishment. "The accessory elements of the composition complete the scene, with the desk of the most proficient scholars, that of the dunce, boys making the 'horns' gesture to one another, pupils who are distracted, others who are studious, and the comical face of the schoolmaster". 40

From the paintings, it can be considered that the normal method was the method of choice in these schools, in keeping with ministerial guidelines. A further relevant aspect is that these paintings - and specifically the works by Toma and Cosola - contain the first representations of schoolmistresses that we have encountered; although our sample of paintings on rural schools in southern Italy feature no female teachers whatsoever, by the late nineteenth century women made up a significant proportion of elementary school teachers. These paintings offer a portrait of town and city schools in the years following Unification that is entirely aligned with the recommendations of modern educational theory and the prescriptions in school legislation. Indeed, the

severity of the education received in religious-run boarding schools, in which "a choleric friar" tamed the spirits of young students by preventing them from "jumping, being at leisure, joking, growing”, and returning them to their families "mogi, grulli ed innocenti / come tanti pecori" [disheartened, foolish and innocent / like so many sheep]. In contrast with this form of captivity practiced by boarding schools, Giusti advocated the educational theories of the "modern educator", whose awareness that "l'uomo tra $i$ viventi messo / qui co' semoventi / par che debba muoversi” [man among the living placed, / here with the self-propelled / it seems as though move he must], meant that "ha pescato nel gran vuoto / la teorica del moto / applicata agli uomini" [he has fished out of the great void / the theory of motion / applied to men] (Giuseppe Giusti, Versi editi ed inediti (Florence: Le Monnier, 1852), 162-165).

39 Giacomo Mantegazza also created other school-themed works, such as the intensely patriotic painting on which the color lithograph is based: Mazzini iniziatore in Londra nel 1841 della scuola per fanciulli poveri italiani, 1896, 22.6 x $28.1 \mathrm{~cm}$. [Museo Nazionale del Risorgimento Italiano - Gabinetto delle Stampe, Turin - Italy].

40 “Chi la fa l'aspetta," in L'Illustrazione Italiana 41 (1881): 234. The scene depicted in this painting proves that despite a body of guidelines and legislation, teachers continued to make use of corporal punishment in many Italian schools, as is also borne out by the oral testimonies of numerous individuals who attended school as recently as the 1970s and 1980s. 


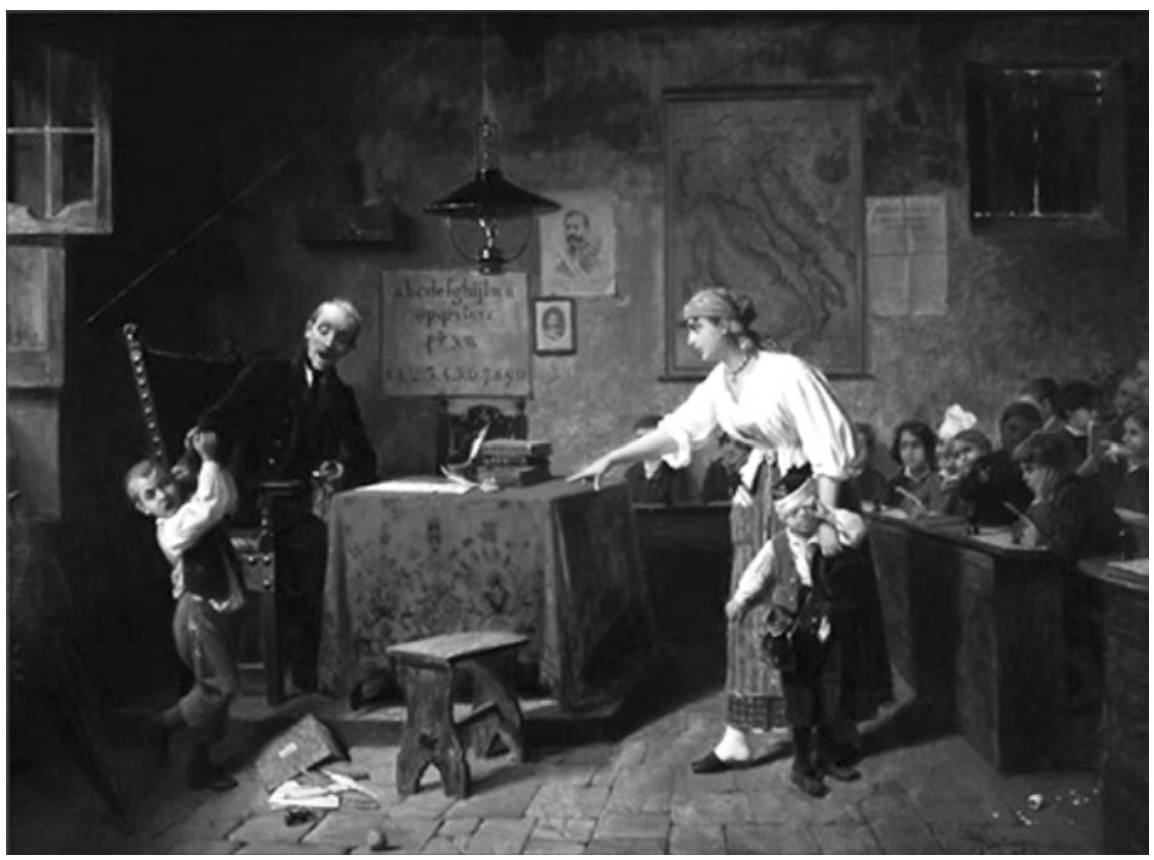

Fig. 10.5: Giacomo Mantegazza, La lezione allo scolaro o Chi la fa l'aspetta, oil on canvas, n.d., 76.2 x $105.4 \mathrm{~cm}$. [Private collection].

urban schools appear to be perfect: a far cry from that we could name "impossible schools" that were often the only option available to children from rural families in the southern interior, where it would appear that "Italy" had not yet become a reality.

\section{Visual sources and image credits}

Alessandro Battaglia (1870-1940), In classe, oil on canvas, 1897, 87.6 x $174.6 \mathrm{~cm}$. [Private collection ${ }^{41}$ ]

Francesco Bergamini, Il maestro di scuola, oil on canvas, n.d., $50 \times 81,5 \mathrm{~cm}$. [Private collection ${ }^{42}$ ]

41 The painting - authenticated by the artist himself - was sold under the title "School room" (Lot 151) by Sotheby's of New York on October 29, 1987 at an auction entitled "Important Nineteenth Century European Paintings, Drawings and Watercolors".

42 The painting - authenticated by the artist - was put up for auction under the title "The school teacher" (Lot 143) by Sotheby's of London on June 15, 2017 as part of an auction entitled "Tableaux, sculptures et dessins anciens et du 19e siècle"; however, with an estimated value of €6,000 $€ 8,000$, it failed to sell. 
Francesco Bergamini, La classe indisciplinata, oil on canvas, n.d., $50.8 \times 81.3 \mathrm{~cm}$. [Private collection ${ }^{43}$ ]

Francesco Bergamini, La lezione, oil on canvas, n.d., $50 \times 81 \mathrm{~cm}$. [Private collection ${ }^{44}$ ]

Francesco Bergamini, L'alunno disubbidiente, oil on canvas, n.d., $55.3 \times 90 \mathrm{~cm}$. [Private collection; ${ }^{45}$ Fig. 10.2]

Francesco Bergamini, L'aula, oil on canvas, n.d., $52 \times 84 \mathrm{~cm}$. [Private collection ${ }^{46}$ ]

Francesco Bergamini, La visita del curato, oil on canvas, n.d., $51 \times 83.2 \mathrm{~cm}$. [Private collection ${ }^{47}$ ]

Francesco Bergamini, Lezione di catechismo, oil on canvas, n.d., $50 \times 81 \mathrm{~cm}$. [Private collection ${ }^{48}$ ]

Francesco Bergamini, Scuola domenicale, oil on canvas, n.d., 44.4 x $67.3 \mathrm{~cm}$. [Hermitage Gallery, Rochester - Michigan - United States of America ${ }^{49}$ ]

Francesco Bergamini (1850-post 1905), Una lezione importante, oil on canvas, n.d., $50.5 \times 81 \mathrm{~cm}$.

[Private collection; ${ }^{50}$ Fig. 10.1]

43 The painting - authenticated by the artist - was sold for US $\$ 28,125$ under the title "The unruly classroom" (Lot 114) by Sotheby's of London on June 6, 2008 at an auction entitled "Old Master \& Nineteenth Century European Art."

44 The painting - authenticated by the artist - was sold for $€ 9,600$ under the title "La lezione (The lesson)" (Lot 102) at Sotheby's of London between March 29 and May 29, 2001 as part of an auction entitled "Nineteenth Century European Paintings."

45 The painting - authenticated by the artist - was sold for US $\$ 31,250$ under the title "The disobedient pupil" (Lot 92) by Sotheby's of London on June 6, 2008 as part of an auction entitled "Old Master \& Nineteenth Century European Art.”

46 The painting - authenticated by the artist - was sold for $£ 3,800$ under the title "The school room" (Lot 209) by Sworder's of London on March 10, 2015 as part of an auction entitled "Spring country house sale".

47 The painting - authenticated by the artist - was sold for $£ 13,750$ under the title "The curate’s visit" (Lot 380) by Christie's of London on October 29, 2010 as part of an auction entitled "Old Masters \& Nineteenth Century Art".

48 The painting - authenticated by the artist - was sold for €5,000 under the title "Sonntagsschule" (Lot 1212) by the Dorotheum auction house in Vienna on April 23, 2015 as part of an auction entitled "Gemälde des 19. Jahrhunderts".

49 The painting - authenticated by the artist in person - was sold for US $\$ 7,500$ under the title "In the classroom" (Lot 63) by Bonhams of New York on April 25, 2012 at an auction called "European Paintings"; the same painting was sold again for US\$4,375 under the same title (Lot 419) by Bonhams of Los Angeles on June 6, 2017 at an auction entitled "The Elegant Home: Select Furniture, Silver, Decorative and Fine Arts". It is now held at the Hermitage Gallery in Rochester under the title "Summer school". This painting was made into an engraving entitled In der Prüfungsstunde, by the lithographer Franz Seraph Hanfstaengl in Munich and published in: Deutscher Hausschatz 26, no. 31 (1900): 572-573. This same engraving was also published under the title "Une minute difficile: le dernier examen de cathéchisme avant la première communion" in: Soleil du Dimanche 14 (1903): 10-11. In 1898, Hanfstaengl made another engraving entitled Italienische Landschule, again based on a painting by Bergamini.

50 The painting - authenticated by the artist himself - was sold for $£ 10,800$ under the title "A valuable lesson" (Lot 88) by Bonhams of London on June 14, 2006 as part of an auction entitled "Nineteenth Century Paintings". 
Francesco Bergamini, Un dono per il maestro, oil on canvas, n.d., $51 \times 81 \mathrm{~cm}$. [Private collection ${ }^{51}$ ] Francesco Bergamini, Un dono per il maestro, oil on canvas, n.d., $51 \times 81.91 \mathrm{~cm}$. [Private collection ${ }^{52}$ ]

Ferdinando Cicconi (1831-1886), La scuola dei vecchi tempi, oil on canvas, n.d. [Private collection ${ }^{53}$ ]

Ferdinando Cicconi, La scuola sotto i passati governi o La scuola sotto i cessati governi, oil on canvas, n.d. [Private collection ${ }^{54}$ ]

Ferdinando Cicconi, La scuola sotto i cessati governi, sketch, n.d., $19 \times 28 \mathrm{~cm}$. [Private collection, Castel di Lama - Italy]

Demetrio Cosola, L'asilo, oil on canvas, n.d., $90 \times 54 \mathrm{~cm}$. [Private collection]

Demetrio Cosola (1851-1895), Il dettato, oil on canvas, 1891 [Galleria Civica d'Arte moderna e contemporanea, Turin - Italy]

Giuseppe Costantini, Il maestro napoletano, oil on canvas, 1873, $42 \times 59.7 \mathrm{~cm}$. [Auckland Art Gallery Toi o Tāmaki - Mackelvie Trust Collection, Auckland - New Zealand ${ }^{55}$ ]

Giuseppe Costantini (1844-1894), La scuola del villaggio, oil on canvas, 1886, 47.5 × 33.5 [Galleria Nazionale d'Arte Moderna, Rome - Italy; ${ }^{56}$ Fig. 10.3]

Giuseppe Costantini, La scuola del villaggio, oil on canvas, 1888, 40.1 x $63.7 \mathrm{~cm}$. [Calderdale Metropolitan Borough Council Museums and Arts, Halifax - United Kingdom; ${ }^{57}$ Fig. 10.4]

Augusto Daini, La lezione, watercolor on paper, n.d. [Private collection]

Augusto Daini (1860-1920), Scuola di campagna, watercolor on paper, n.d., 21,5 x $36.8 \mathrm{~cm}$. [Private collection ${ }^{58}$ ]

51 The painting - authenticated by the artist - was sold for $£ 9,600$ under the title "A present for teacher" (Lot 93) by Bonhams of London on March 22, 2005 as part of an auction entitled "Nineteenth Century Paintings".

52 The painting - authenticated by the artist - was sold for US $\$ 3,250$ under the title "School Tuition" (Lot 4) by Hindman's of Chicago on May 20, 2020 as part of an auction entitled "American and European Art”. It had come from the Chev. Alex. D'Atri \& Sons Ancient \& Modern Art Gallery in Rome.

53 The artist's widow lent the painting to the Pinacoteca civica of Ascoli Piceno on October 19, 1889 (State Archives of Ascoli Piceno, fond "Comune di Ascoli Piceno", year 1889, box "Istruzione Pubblica”, folder 9) and it was taken back by Quirino Cicconi on December 15, 1913 (State Archives of Ascoli Piceno, fond “Comune di Ascoli Piceno", series "Affari Speciali”, box 69); see Giannino Gagliardi, ed., La Pinacoteca di Ascoli Piceno (Ascoli Piceno: G.G. Editore, 1988), 34.

54 The painting was exhibited at the $1^{\text {st }}$ National Fine Arts Exhibition in Parma in 1870 (Catalogo delle opere esposte nella mostra italiana d'arti belle in Parma (Parma: Tipografia Grazioli, 1870), 13) and again at the second edition of this event in Milan in 1872 (Seconda Esposizione Nazionale di Belle Arti diretta da un comitato eletto dalla Regia Accademia di Brera (Milan: Società Cooperativa fra Tipografi, 1872), 44).

55 The original title has been translated into English as: Neapolitan Schoolmaster.

56 The painting is currently held at the Istituto Nazionale di Documentazione, Innovazione e Ricerca Educativa - INDIRE in Palazzo Gerini in Florence. A rotogravure color print of this painting was produced in 1886 by the Danesi printing company in Rome [Musée National de l'Éducation, Rouen (France)].

57 The original title has been translated into English as: An Italian Village School.

58 See the catalogue for the auction Old Master and Nineteenth Century Drawings and Watercolors, held at Christie's East of New York on January 7, 1981: Old Master and Nineteenth Century Drawings and Watercolors (New York: Christie, Manson \& Woods International Inc., 1981). The original title was translated into English as: The classroom. 
Vincenzo Loria (1849-1939), [original title unknown], watercolor on paper, n.d., $34.3 \times 50.8 \mathrm{~cm}$. [Private collection ${ }^{59}$ ]

Giacomo Mantegazza (1853-1920), La lezione allo scolaro o Chi la fa l'aspetta, oil on canvas, n.d., $76.2 \times 105.4 \mathrm{~cm}$. [Private collection; ${ }^{60}$ Fig. 10.5]

Achille Martelli (1829-1903), Nella scuola del villaggio o O tempora! o mores!, oil on canvas, 1869, $42 \times 62 \mathrm{~cm}$. [Museo delle Arti di Catanzaro - Pinacoteca e Gipsoteca - Collezione della Provincia di Catanzaro, Catanzaro (Italy) $]^{61}$

Antonio Piccinni (1846-1920), A scuola, etching, 1872, 23.6 x $14.4 \mathrm{~cm}$. [Comune di Milano - Civiche Raccolte Grafiche e Fotografiche - Civica Raccolta delle Stampe “Achille Bertarelli," Milan (Italy) $]^{62}$

Gioacchino Toma (1836-1891), L'onomastico della maestra, oil on canvas, 1879, 114 x $75 \mathrm{~cm}$. [Museo di Capodimonte - Fondo “Accademia di Belle Arti di Napoli” - Deposito 42, Naples Italy]

59 The painting - authenticated by the artist - was sold for US\$2,300 under the title "Boys and teacher in a school interior" (Lot 1166) by John Moran auctioneers in Pasadena on December 8, 2009 as part of an auction entitled "Antiques, fine jewelry \& decorative art".

60 The painting was displayed in 1881 at the National Exhibition in Milan along with other works by the same artist (Agostino Mario Comanducci, Dizionario illustrato dei pittori, disegnatori e incisori italiani moderni e contemporanei (Milan: Patuzzi, 1962), 127) and purchased there by the wellknown banker Alberto Weill-Schott for L.1,500 (Sergio Rebora, "Imprenditori, artisti e loro intermediari a Milano dopo l'Unità," Storia in Lombardia 2 (1992): 53). A color print of this painting was made by an unknown artist and published in: L'Illustrazione Italiana 8, 41 (1881): 229. The painting was recently sold for US $\$ 18,000$ under the title "School house discipline" (Lot 1174) by John Moran Auctioneers in Pasadena on November 30, 2010 as part of an auction entitled "Antiques \& Decorative Arts Auction."

61 A ceramic copy, made by Martelli in 1878, is held at the Pinacoteca provinciale of Avellino in Palazzo Caracciolo.

62 Several reprints were made; for the purposes of this study we consulted the first print in the series "Souvenirs de Rome" (12 prints), edited by Cadart in Paris in 1878, and published the following year in the Gazette des Beaux-Arts under the title "Un école à Rome," in support of a review of that year's edition of the Salon de Paris - the official exhibition of the Académie des Beaux-Arts (Arthur Baignères, "Le Salon de 1879 (troisième et dernier article)," Gazette des Beaux-Arts 20, no. 2 (1879), 158-159). It is interesting to note how the graphic composition of the scene recalls that of the etching: Tre bambine in piedi, n.d. (but later than 1888), $9.5 \times 16.2 \mathrm{~cm}$. [Comune di Milano - Civiche Raccolte Grafiche e Fotografiche - Civica Raccolta delle Stampe "Achille Bertarelli”, Milan (Italy)]. The etching A scuola is reproduced in: Antonio Piccinni incisore. Catalogo ragionato dell'opera grafica, ed. Fabio Fiorani and Giovanna Scaloni (Roma: De Luca, 2005). 


\section{Bibliography}

Agresta, Salvatore, and Caterina Sindoni. Scuole, maestri e maestre nelle Calabrie borboniche (1817-1860). Lecce, Rovato: Pensa Multimedia, 2016.

Agresta, Salvatore, and Caterina Sindoni. Scuole, maestri e metodi nella Sicilia borbonica (1817-1860). Lecce, Rovato: Pensa Multimedia, 2012.

Avella, Leonardo. Giuseppe Costantini da Nola, artista pittore. Naples, Rome: Libreria Editrice Redenzione, 1980.

Baignères, Arthur. "Le Salon de 1879 (troisième et dernier article)." Gazette des Beaux-Arts 20, no. 2 (1879): 158-159.

Burke, Catherine. "Containing the School Child: Architectures and Pedagogies." Paedagogica Historica 41, no. 4-5 (2005): 489-490.

Burke, Peter. Eyewitnessing: The Use of Images as Historical Evidence. London: Reaktion Books, 2001.

Caruso, Marcelo, ed. Classroom Struggle: Organizing Elementary School Teaching in the Nineteenth Century. Frankfurt: Peter Lang, 2015.

Catalogo Bolaffi della pittura italiana dell'Ottocento, no. 8. Turin: Bolaffi, 1979.

Catalogo Bolaffi della pittura italiana dell'Ottocento, no. 10. Milan: Mondadori, 1981.

Catalogo dell'arte italiana dell'Ottocento, no. 13. Milan: Mondadori, 1984.

Catalogo dell'arte italiana dell'Ottocento, no. 14. Milan: Mondadori, 1984.

Catalogo delle opere esposte nella mostra italiana d'arti belle in Parma. Parma: Tipografia Grazioli, 1870.

“Chi la fa l'aspetta." L'Illustrazione Italiana 41 (1881): 234.

Chiosso, Giorgio. Alfabeti d'Italia: la lotta contro l'ignoranza nell'Italia unita. Turin: Società Editrice Internazionale, 2011.

Collelldemont, Eulàlia. “La memoria visual de la escuela." Educatio Siglo XXI 28, no. 2 (2010): 133-156.

Comanducci, Agostino Mario. Dizionario illustrato dei pittori, disegnatori e incisori italiani moderni e contemporanei. Milan: Patuzzi, 1962.

Cristofani, Antonio. Delle storie di Assisi. Assisi: Tipografia Metastasio, 1902.

Dekker, Jeroen J.H. "Images as Representations: Visual Sources on Education and Childhood in the Past." Paedagogica Historica 51, no. 6 (2015): 702-715.

Dekker, Jeroen J.H. "The Restrained Child: Imaging the Regulation of Children's Behaviour and Emotions in Early Modern Europe, The Dutch Golden Age." History of Education \& Children's Literature 13, no. 1 (2018): 17-39.

Del Pozo Andrés, María del Mar, and Sjaak Braster. "Exploring New Ways of Studying School Memories: The Engraving as a Blind Spot of the History of Education." In School Memories. New trends in the History of Education, edited by Cristina Yanes-Cabrera, Juri Meda and Antonio Viñao, 11-27. Cham: Springer, 2017.

Depaepe, Marc, et al. Order in Progress. Everyday Educational Practice in Primary Schools (Belgium, 1880-1970). Louvain: Leuven University Press, 2000.

Depaepe, Marc, and Bregt Henkens, eds. "The Challenge of the Visual in the History of Education." Paedagogica Historica 36, no. 1 (2000).

Dussel, Inés and Marcelo Caruso. La invención del aula. Una genealogía de las formas de enseñar. Buenos Aires: Santillana, 1999.

Esposizione Italiana Agraria, Industriale e Artistica tenuta in Firenze nel 1861: catalogo ufficiale. Florence: Tipografia Barbèra, 1862.

Ferrigni, Pietro. Fra quadri e statue: strenna ricordo della II Esposizione nazionale di belle arti. Milan: Treves, 1873. 
Fiorani, Fabio, and Giovanna Scaloni, eds. Antonio Piccinni incisore. Catalogo ragionato dell'opera grafica. Rome: De Luca, 2005.

Formiggini Santamaria, Emilia. L'istruzione popolare nello Stato Pontificio, 1824-1870. Bologna: A.F. Formiggini Editore, 1909.

Gagliardi Giannino, ed. La Pinacoteca di Ascoli Piceno. Ascoli Piceno: G.G. Editore, 1988.

Genovesi, Ezio. "Francesco Bergamini pittore." Subasio: trimestrale di informazioni culturali 6, no. 4 (1998): 22-23.

Genovesi, Ezio, and Emilio Lunghi, eds. Arte ad Assisi: 1882-1942. Catalogo della mostra. Bastia Umbra: Grafiche Diemme, 1993.

Giusti, Giuseppe. Raccolta di proverbi toscani. Florence: Le Monnier, 1853.

Giusti, Giuseppe. Versi editi ed inediti. Florence: Le Monnier, 1852.

Gómez Naranjo, Juan Antonio. "La escuela del Siglo XVII, según la pintura de Jan Steen.” Anales de historia del arte 21, no. extra 1 (2011): 241-247.

Grosvenor, Ian. "On Visualizing Past Classrooms." In Silences and Images: The Social History of the Classroom, edited by Ian Grosvenor, Martin Lawn, and Kate Rousmaniere, 83-104. New York: Peter Lang, 1999.

Howard, Jeremy Charles. "Classroom Genres: Aspects, Values and Interpretations of Painted School Interior Scenes." In The Black Box of Schooling: A Cultural History of the Classroom, edited by Sjaak Braster, Ian Grosvenor and María del Mar del Pozo Andrés, 59-77, 292-293, 313-317. Brussels: Peter Lang, 2011.

Howard, Jeremy Charles. "Le traitement artistique de la culture matérielle à l'école." In Éducation et culture matérielle en France et en Europe du XVIe siècle à nos jours, edited by Marguerite Figeac-Monthus, 219-246. Paris: Honoré Champion, 2018.

Leone, Giorgio. "La Calabria tra Napoli e il resto d'Italia. La 'pittura di interno' come un episodio pittorico della cultura artistica del Mezzogiorno nella seconda metà dell'Ottocento.” In Poesia d'interni angoli di vita nell'arte dell'800 italiano, edited by Antonio D'Amico, 17-22. Milan: Edizioni Bocca, 2010.

Luna, Luca. Ferdinando Cicconi. Ascoli Piceno: D’Auria Editrice, 1996.

Lupo, Maurizio. Tra le provvide cure di Sua Maestà: Stato e scuola nel Mezzogiorno tra Settecento e Ottocento. Bologna: Il Mulino, 2005.

Mammucari, Renato. Acquerellisti romani: suggestioni neoclassiche, esotismo orientale, decadentismo bizantino, realismo borghese. Città di Castello: Edimond, 2001.

Mantura, Bruno, and Nicola Spinosa, eds. Gioacchino Toma: 1836-1891. Catalogo della mostra. Naples: Electa, 1995.

Marcus, Thomas. "Early Nineteenth Century School Space and Ideology." Paedagogica Historica 32, no. 1 (1996): 9-50.

Mariani, Raffaele. "Castighi scolastici di altri tempi." I Diritti della Scuola 30, no. 13 (1929): 605.

Marini, Giuseppe Luigi, ed. Il valore dei dipinti italiani dell'Ottocento e del primo Novecento: analisi critica, storica ed economica. Turin: Allemandi \& Co., 1995.

Marini, Giuseppe Luigi, ed. Il valore dei dipinti italiani dell'Ottocento e del primo Novecento: analisi critica, storica ed economica. Turin: Allemandi \& Co., 2007.

Marini, Giuseppe Luigi, ed. Il valore dei dipinti italiani dell'Ottocento e del primo Novecento: analisi critica, storica ed economica. Turin: Allemandi \& Co., 2009.

Meda, Juri and Antonio Viñao. "School Memory: Historiographic Balance and Heuristic Perspectives." In School Memories. New Trends in the History of Education, edited by Cristina Yanes-Cabrera, Juri Meda and Antonio Viñao, 1-9. Cham: Springer, 2017.

Meda, Juri, and Marta Brunelli. "The Dumb Child: Contribution to the Study of the Iconogenesis of the Dunce Cap." History of Education \& Children's Literature 13, no. 1 (2018): 41-70. 
Melton, James Van Horn. Absolutism and the Eighteenth-Century Origins of Compulsory Schooling in Prussia and Austria. Cambridge: Cambridge University Press, 1988.

Mercurelli Salari, Paola. I disegni di Francesco Bergamini per la perduta decorazione ottocentesca della cattedrale di San Rufino ad Assisi. Assisi: Circolo del Subasio, 2005.

Ministero della Istruzione Pubblica - Direzione generale per le antichità e le belle arti. Notizie intorno alle scuole d'arte e di disegno italiane. Rome: Tipografia Cecchini, 1898.

Morandini, Maria Cristina. Scuola e nazione: maestri e istruzione popolare nella costruzione dello Stato unitario (1848-1861). Milan: Vita e Pensiero, 2003.

Nóvoa, António. "Ways of Saying, Ways of Seeing: Public Images of Teachers

(nineteenth-twentieth Century)." Paedagogica Historica 36, no. 1 (2000): 20-52.

Old Master and Nineteenth Century Drawings and Watercolors. New York: Christie, Manson \& Woods International Inc., 1981.

Ovidi, Ernesto. Tommaso Minardi e la sua scuola. Rome: Tipografia Pietro Rebecca, 1902.

Picone Petrusa, Mariantonietta. "Costantini Giuseppe." In Dizionario biografico degli Italiani, vol. 30. Rome: Istituto dell'Enciclopedia Italiana, 1984.

Picone Petrusa, Mariantonietta. “Costantini Giuseppe.” In La pittura napoletana dell'Ottocento, edited by Franco Carmelo Greco, Mariantonietta Picone Petrusa and Isabella Valente, 112. Naples: Tullio Pironti editore, 1993.

Polenghi, Simonetta. "Elementary School Teachers in Milan During the Restoration (1814-59): Innovations and Improvements in Teacher Training." History of Education \& Children's Literature 8, no. 1 (2013): 147-166.

Polenghi, Simonetta. "La pedagogia di Felbiger e il metodo normale." Annali di Storia dell'Educazione e delle Istituzioni Scolastiche 8 (2001): 245-268.

Priem, Karin, Inés Dussel, and Marc Depaepe, eds. "Images and Films as Objects to Think With: A Reappraisal of Visual Studies in Histories of Education." Special issue. Paedagogica Historica 53, no. 6 (2017).

Prosser, Jon. "Visual Methods and the Visual Culture of Schools." Visual Studies 22, no. 1 (2007): 13-30.

Rebora, Sergio. "Imprenditori, artisti e loro intermediari a Milano dopo l'Unità." Storia in Lombardia 2 (1992): 47-74.

Ricci, Paolo. "Gioacchino Toma e la pittura meridionale dell’Ottocento." Società 11, no. 3 (1955): 458-479.

Rigutini, Giuseppe. Vocabolario della lingua italiana. Florence: Barbèra, 1874.

Rousmaniere, Kate. "Questioning the Visual in the History of Education." History of Education 30, no. 2 (2001): 109-111.

Santucci, Domenico. Guida dei precettori d'ambo i sessi e padri di famiglia per le scuole elementari comunali e private. Naples: Tipografia Agrelli, 1843.

Seconda Esposizione Nazionale di Belle Arti diretta da un comitato eletto dalla Regia Accademia di Brera. Milan: Società Cooperativa fra Tipografi, 1872.

Sulle condizione della pubblica istruzione nel Regno d'Italia: relazione generale. Milan: Stamperia Reale, 1865.

Valente, Isabella. "Centro e periferia: itinerari italiani di alcuni artisti calabresi tra Ottocento e Novecento." In L'animo e lo sguardo: pittori calabresi dell'Ottocento di Scuola napoletana. Catalogo della mostra, edited by Tonino Sicoli and Isabella Valente, 17-34. Cosenza: Progetto 2000, 1997.

Vocabolario degli Accademici della Crusca, vol. 2. Florence: Tipografia Galileiana, 1866.

Zanotti Bianco, Umberto. Il martirio della scuola in Calabria. Florence: Vallecchi, 1925. 